\title{
CROSS-BORDER COOPERATION IN RURAL TERRITORIES IN CONTEXT OF THE EU FUNDS: CASE OF LATVIA-ESTONIA-RUSSIA BORDER AREA
}

\author{
Santa Daume ${ }^{\prime \prime}$ PhD Cand. \\ ${ }^{1}$ University of Latvia
}

\begin{abstract}
Cross-border cooperation ( $\mathrm{CBC}$ ) has become an object for academic debates during the last decades, mostly because of open border policy in the European Union (the EU) and because of spatial and social changes it has created. To analyse role of the EU funded activities on promoting CBC in Latvia-Estonia-Russia border area, two case studies were selected - Aluksne Region in Latvia as a main case and Voru County in Estonia as a satellite case.

Main findings reveal that the EU open borders and cohesion policy have an important role in promoting formation of $\mathrm{CBC}$. The main influence of the $\mathrm{EU}$ is related to financial support of $\mathrm{CBC}$ projects, which is also considered to be the main precondition for creating $\mathrm{CBC}$ in the Latvia-Estonia-Russia border area. It coincides with other research works done in different regions across Europe.
\end{abstract}

Key words: cross-border cooperation, regional development, the EU funding, Latvia-Estonia-Russia border. JEL code: R58

\section{Introduction}

Despite the development of regional policy and efforts to resurrect rural regions, regional development indicators (business activity, population, availability of services, employment, development of innovations etc.) in Latvia still show too great disproportions between both planning regions and municipalities comparing to other EU countries (The Ministry of Environmental Protection and Regional Development of the Republic of Latvia, 2013). This leads scholars to reevaluate approaches for territorial development. Aim of this paper is to discuss impact of the EU funded activities on international $\mathrm{CBC}$ and its outcome. Research object - cross-border cooperation. Accordingly, research tasks are: to operationalize the concept of $\mathrm{CBC}$; to reveal if the EU funding is being used in studied area in context of CBC.

Borders' policy has an important role in CBC and mobility. Professor of political science Serghei Golunov studying the EU and Russia relations has discovered that strict conditions for border crossing and troublesome border crossing hinder mutually beneficial cooperation - trade, tourism, culture and other (Golunov S., 2013). It cannot be denied that troublesome border crossing (the EU external borders) has influence on formation of $\mathrm{CBC}$, as well as on creating conditions that differ from the EU internal border and thus has influence on regional development.

A case of Latvia-Estonia-Russia border area is interesting for an academic study because region includes both the ES internal (Latvia-Estonia) and the ES external (Latvia-Russia; Estonia-Russia) borders. It is attractive also because of options for border crossing and potential for CBC.

\section{Research results and discussion}

\section{Concept of Cross-Border Cooperation}

The Council of Europe defines $\mathrm{CBC}$ as "concerted process of building neighbourly relationships between local stakeholders and authorities on either side of a border, with a view to overcoming such problems and fostering harmonious development of neighbouring communities" (The Council of Europe, 2012). However, further operationalization is required to use the concept of "crossborder cooperation" as a basis for theoretical analysis. Four main aspects of CBC can be detected:

1) as main leaders of $C B C$ usually are public authorities, it must be analysed within a framework of public agency;

1 Mob:+371 26633506, e-mail: santa.daume@gmail.com 
2) $C B C$ is usually referred to sub-national local authorities, who normally do not have rights to conclude international contracts according to the international law. That is why usually $C B C$ is rather based on informal or semi-formal agreements;

3) the aim of CBC commonly is related to solving some practical issues concerning all parties involved;

4) $C B C$ involves stabilization of contacts - it can manifest, for example, as establishing of a crossborder institution (Perkmann M., 2003).

Summarizing these aspects, the basis of CBC includes - public nature of cooperation, a role of sub-national local authorities, solving practical issues and importance of stability of cross-border contacts.

According to the Council of Europe, the main aims to create $\mathrm{CBC}$ in border areas are:

1) to promote the socio-economic development of the border area (for example, to attract financial support);

2) to improve employment opportunities, to use the own resources and capital of regions in an efficient way etc.);

3) to develop and provide better services (for example, health-care, education, transport infrastructure etc.);

4) to widen cultural perspectives (for example, to promote bilingualism, cultural diversity, a nonideological interpretation of history and mutual knowledge and trust etc.) (The Council of Europe, 2012).

One of the main triggers for $\mathrm{CBC}$ and emergence of cross-border regions in the European countries is the EU regional and cohesion policy already since 1989, and it is the most funded instrument - the INTERREG Community Initiative. Its purpose has been to reduce a barrier among countries and to achieve goals of the European Spatial Development Perspective (The ESPON, 2007). CBC within the framework of the INTERREG financial instrument can be implemented among the EU countries only, as well as involving countries outside the EU. Availability of this practical financial instrument creates both economic and social conditions for emergence of financial support for newly created cross-border cooperation; understanding of CRC process and communication; as well as agreement on common goals to be achieved as a result of cooperation.

As researcher of political and social sciences Luis de Sousa points out, the EU regional and open borders policy and integration have had instant, as well as sustainable outcome. Opening of the most of the EU's internal borders can be considered as an instant result, while creation of suitable conditions for $\mathrm{CBC}$ and innovation can be considered as a long-term and sustainable result of the EU actions (de Sousa L., 2013). CBC can be perceived as a process where parties involved and their representatives interact to achieve desirable and expected results or to optimize and use efficiently the own resources of territories. Several academic disciplines during the time have tried to explain $\mathrm{CBC}$ without paying attention to social transactions or importance of building productive relationships and social networks. However, cooperation must be perceived as "investment in contacts and relationships that represent opportunities that could promote social and economic integration in present and future times" when studying formal or informal cross-border relations (Gonzalez-Gomez T. \& Gualda E., 2014).

Analysing $\mathrm{CBC}$ in Euroregions, Polish sociologists Joanna Fratczak-Muller and Anna Mielczarek-Zejmo conclude that $\mathrm{CBC}$ and the border aspect have a crucial role in development of local communities (Fratczak-Muller J. \& Mielczarek-Zejmo A., 2016). In context of global changes, 
diverse regional development and the EU cohesion and borders policy, capability of regions to adapt and restructure are crucially important. Successful development of rural regions in Europe is related exactly to $\mathrm{CBC}$ to a large extent - investments and $\mathrm{CBC}$ projects in all possible areas, improvement of infrastructure (both cross-border and in the central part of the state), $C B C$ in academic level (universities, research facilities) are few of characteristics of successful rural territories (AEBR, 2008b). Also social aspects, as experience of parties involved, informal social networks, language knowledge, as well as personal involvement of local inhabitants have a significant role in creating successful CBC. Whereas, dynamics, extent and field of CBC depend on ideas and commitment of parties involved, on skills and capacity of local authorities, as well as on institutional support and recognition of local community (Fratczak-Muller J. \& Mielczarek-Zejmo A., 2016).

Although a lot of efforts to promote $\mathrm{CBC}$ in Europe have been made during the last decades, there are still a lot of challenges to achieve a sustainable and proven model of cooperation, which would contribute to development and improvement of economic, as well as social, political, cultural and environmental issues of border regions via CBC (Castanho R., Loures L., Fernandez J. \& Pozo L., 2016).

\section{Data and methods}

Latvia and Estonia joined the EU in 2004. Estonia in 2011 and Latvia in 2014 both entered the Eurozone and started using euro as a currency. Since 2007, when both countries entered the Schengen Agreement, Latvia-Estonia has lifted a mutual border control. Although inhabitants of the border area have eased conditions for Russia's border crossing and they do not necessary need to receive a visa, they still face annoyance to cross the border (The Cabinet of Ministers of the Republic of Latvia, 2010).

Source: author's created

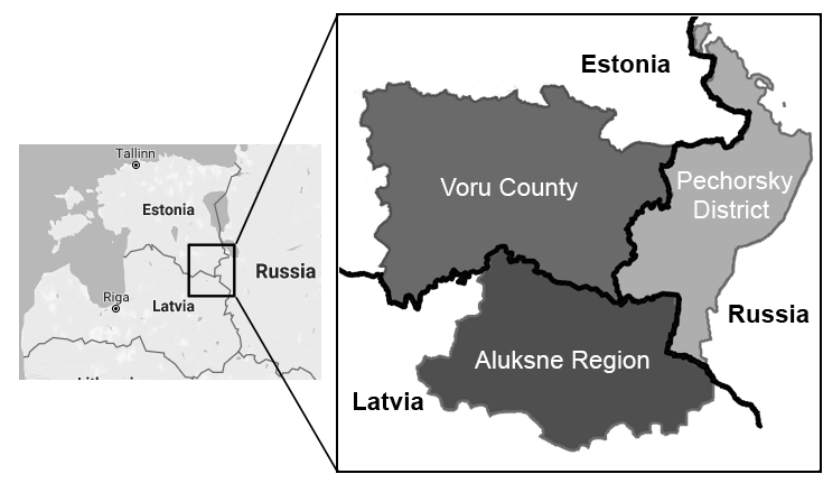

Fig. 1. Studied area

Municipality of Aluksne Region has signed several cooperation agreements with cross-border municipalities in Estonia and Russia ad with other public or private bodies. The main goal of CBC is to attract the EU or other international funds for promoting development of all parties involved (The Municipality of Aluksne Region). Two or three sided cooperation including Aluksne Municipality has implemented projects mostly using the INTERREG instrument funded by the European Commission (http://www.interregeurope.eu/).

Fourteen semi-structured interviews with local stakeholders and inhabitants of both sides of the border were conducted during May 2016 and July 2017 to obtain empirical data. In addition, quantitative survey of 200 inhabitants of Aluksne Region was carried out during December 2016. 


\section{Results}

To better understand impact of the EU funded activities on CBC in Latvia-Estonia-Russia border area, it's important to briefly describe the context of different conditions created by the EU internal (Latvia-Estonia) and external (Latvia-Russia) border. When explaining the conditions created by close proximity of border both inhabitants and experts use comparison between the EU internal and external border to point out differences created by each of them. For example:

"Closed border - it's a loss, if opened - it's a benefit, because it is also cross-border cooperation. Economic benefit can be gained definitely when cooperating across the border." (Vitola D., 2017).

Also inhabitants have perceived differences created by both borders - $68 \%$ of respondents of quantitative survey are convinced that borders of Estonia and Russia each creates different conditions for development of Aluksne Region. Majority (70\%) of respondents admit that close proximity of Estonian border positively influences the economic development of Aluksne Region. While regarding close proximity of Russian border - less than a half ( $44 \%$ ) of respondents think that it positively influences the economic development of the territory (Daume S., 2016).

Although border regions of Latvia-Estonia border have CBC also with neighbours in Russia, cooperation between border territories of Latvia-Estonia border and between its inhabitants is more frequent. The main reason for this is the EU internal border policy, which makes cross-border mobility more convenient. Based on survey data, $91 \%$ of all respondents have visited Estonia during the past three years and $45 \%$ of them have had any type of cooperation or direct contacts with inhabitants of Estonia (including CBC projects, personal contacts, business contacts etc.). While only $27 \%$ of respondents have visited Russia during the past three months and only $24 \%$ have had any type of cooperation or direct contacts with inhabitants of Russia. Inhabitants, as well as local executives are aware and assess advantages of the open borders policy cooperation and mobility at individual, as well as institutional level is possible without specific border-related requirements. Despite the differences in conditions created by borders, $C B C$ are evaluated mostly positively regardless of the direction between which countries it is being implemented (Vartukapteine I., 2016; Vitola D., 2016; Gotmans J., 2016; Mark J., 2016; Vahter B., 2017; Tali T., 2017; Prizavoite A., 2017; Dukulis A., 2017). At the same time, the researcher must be cautious to make persuasive and strict conclusions about the desired highly developed $\mathrm{CBC}$ in the future. Finnish social anthropologist Laura Assmuth a decade ago pointed out that there are social groups (entrepreneurs, intellectuals, regional and the EU bureaucrats) in the Latvia Estonia-Russia border area, which have "high hopes for this area becoming an international crossroads instead of a 'back pocket' of three strictly separate states"' (Assmuth L., 2006).

The main reasons why $\mathrm{CBC}$ could be beneficial are challenges and areas for development in both sides of the border are the same (mostly workplaces and transport infrastructure), so they could be solved and developed efficiently by working together and sharing knowledge and experience (Vartukapteine I., 2016; Raidma M, 2016; Vahter B, 2017); it creates more opportunities to raise the EU or other international funds when more than one country is involved (Mark J., 2016; Prizavoite A., 2017).

The EU cohesion policy and one of its main goals - territorial cooperation in Europe - can be considered as one of the most crucial preconditions to create CBC both within borders of the EU and outside it. Although municipalities, NGOs and other organizations, as well as entrepreneurs can 
take part in $\mathrm{CBC}$ programs funded by the EU, in the case of Latvia-Estonia-Russia border area local municipalities have been the most active partners implementing both two and three sided cooperation. In the previous 2007 - 2013 planning period entrepreneurs and NGOs did not take part very actively, mainly because of procedures required including finance control and audit. Also because of time needed to prepare proposal, but without confidence about confirmation of the project (Nikopensius, 2017). Current CBC programs are active until 2020, so it's too soon to make conclusions about their results.

The EU funding promotes $\mathrm{CBC}$, as well as creates new opportunities for more attractive local living environment (Vahter B., 2017; Sarmite, 2017). In the previous planning period of 2007 -2013, specifications and fields of supported projects were broader and without many restrictions, but in the latest planning period (2014 - 2020) priorities of industries are being set.

Stakeholders from both Aluksne Region and Voru County admit that by large extent territorial development can happen because of the EU financial support in framework of CBC programs, for example, renovation of buildings owned by local municipality, new objects construction, purchase of technical equipment, transport and other technological devices required for maintenance of territory, development of tourism objects, as well as organizing culture and sport events (Raidma M., 2016; Mark J, 2016; Vahter B, 2017; Dukulis A., 2017; Rozite M., 2017). Chairman of Council of Aluksne Municipality is convinced that EST-LAT CBC program is the tool which can help to smooth out an unequal development between centre and border area of the state (Dukulis, 2017).

Benefits of the EU funded CBC programs manifest not only as reaching a certain goal of a project, but also as giving opportunity for wider society to gain economic benefits, for example, to realize products of local crafters or local SME within the framework of CBC, and as creating and maintaining international social ties and communication. The interviewed stakeholders admit that newly formed social ties and networks are very important to identify common problems, to set goals and to exchange experience and knowledge to work more efficiently. One of the basic conditions for successful CBC is mutual trust, which generally occurs as a result of long-term cooperation and positive previous experience. Although the EU funding is the main precondition to create $\mathrm{CBC}$ in the first place, nevertheless sustainable social outcome can be identified development of social networks and using newly formed social ties to discuss and to search for solutions for other challenges and interests beyond projects funded by the EU (Vahter B., 2017; Dukulis A., 2017; Rozite M., 2017; Gotmans J., 2016; Mark J., 2016; Raidma M., 2016; Prizavoite A., 2017).

Local amateur collectives, NGOs, as well as afterschool interest groups for pupils are usually involved in the ES funded projects in field of culture, as well as in other cross-border activities, which accordingly takes an important role in implementing $C B C$ and in diversification of everyday life of local community. These local initiatives become a mediator between cross-border cooperation in institutional and individual level, because they promote engagement of local inhabitants into institutional level CBC between local municipalities or other partners. Especially this link can be observed in field of culture, because $C B C$ in this field allows local inhabitants to take part into various international events (Rozite M., 2017; Vahter B., 2017; Vartukapteine I., 2016; Raidma M., 2016; Ede, 2016; Solveiga, 2017). This type of cooperation leads to development of new options for local inhabitants and further - to create more attractive living environment. This result of $\mathrm{CBC}$ can be considered as one of potential solutions to unresolved problem of inhabitants leaving peripheral territories of both Latvia and Estonia. The Head of 
Department of Planning and Development of Voru County Municipality in Estonia directly relates the EU funded activities with more attractive living environment in rural territories:

"I am very happy about EST-LAT program. [..] Community is very small, here is not a lot of new everyday things, population can't go to theatre or cinema every day, thus daily entertainment offer is very small. But when there are projects which support cooperation between communities, it enriches their life. That increases quality of life and I think that it is very good. If there are no people, then there is nothing to develop. " (Vahter B., 2017).

Still, some limitations of the EU funded activities can be identified in case of Latvia-EstoniaRussia CBC nowadays. CBC within studied area in Latvia-Estonia-Russia border area is not as frequent as it was a few years ago. The main reason for that is the end of activities funded by the INTERREG IIIC program in 2008. A large part of CBC projects has been related to renovation, construction or improving infrastructure, but along with changes in the EU funding options, nowadays financial support can be received more frequent for projects related to social aspects of territory or local community (for example, learning experience exchange, conferences etc.) instead of construction, renovation and similar projects - this is the main reason, why CBC with involvement of local governments has decreased during the last years:

"Of course, it would be possible to cooperate more, but it is necessary to see, how much money, what are the options, where we can write a project. There are "soft" projects, seminars, because old Europe has already constructed, developed its objects in parishes, they want seminars, learning. But new Europe wants to invest, to construct, to renovate." (Raidma, 2016).

Another limitation can be identified in relation to change of the EU funding conditions and prioritizing the industries as mentioned above. Although for the latest planning period the focus of supported actions and industries are more determined as before, now there are limitations to receive funding for a wide range of projects the results of which would be useful for local community and individuals. In the latest program, culture and sport related projects are not supported, so there are not many projects which promote interaction and fellowship between the nations (Nikopensius, 2017). For 2014 - 2020 programs' period, there is separately divided Estonia-Latvia and Latvia-Russia CBC programs, because of different goals and mutual problems to be solved. Still, mission is similar for both - to promote development of both countries by using opportunities provided by CBC (INTERREG Estonia - Latvia; Latvia - Russia Cross-border Cooperation Programme). The main priorities for Estonia-Latvia program are:

1) active and attractive business environment;

2) clean and valued living environment;

3) better network of harbours;

4) integrated labour market (INTERREG Estonia - Latvia).

While the main priorities for Latvia-Russia CBC program are:

1) business and SME development;

2) environmental protection, climate change mitigation and adaptation;

3) promotion of border management and border security, mobility and migration management (Latvia - Russia Cross-border Cooperation Programme).

Closeness of $\mathrm{CBC}$ and long-term interaction is one of the main criteria to be measured in order to attract funds from the EU funded $\mathrm{CBC}$ programs. 


\section{Conclusions, proposals, recommendations}

1) In this research paper, the author theoretically, as well as empirically analysed the concept and process of $C B C$ and focused her analysis on role of the EU financing instruments on CBC. The EU cohesion and open borders' policy have promoted development of $C B C$ by ensuring one of the most crucial preconditions for $\mathrm{CBC}$ - financial funding.

2) The EU financing instruments, as well as the EU cohesion and open borders policy directly, as well as indirectly influence development of border area and promote formation of international social ties.

3) The type of supported activities by the EU has an important role in sustaining CBC - changes of the EU funding programs in favour of projects which are rather focused on social activities (instead of projects of construction or infrastructure) have decreased overall CBC in border area of Latvia-Estonia-Russia.

4) On the one hand, cultural and long-term interaction is very important to promote development - also evaluation criteria for the EU funded projects confirms it, on the other hand, those case studies showed that there is still a need for funding construction and renovation projects, for which it is not necessary to have high level of cross-national interaction and establishing long term relations. Since the EU countries are in different stages of economic and social development, priorities for funding should be set based on level of countries' development and based on in-depth analysis of local needs.

This paper was funded by LU research project "PUBLIC HEALTH, QUALITY OF LIFE AND SUSTAINABLE NATION" (LU reg.Nr. ZD2016/AZ117).

\section{Bibliography}

1. AEBR (2008a). Cooperation Between European Border Regions, AEBR - NOMOS, Baden-Baden.

2. AEBR (2008b). Growing Regions, Growing Europe: Public Consultation on the Future of the EU Cohesion Policy, January 29, pp. 12. Retrieved:

http://www.aebr.eu/files/publications/Association_of_European_Border_RegionsEN.pdf. Access: 06.02.2018.

3. Assmuth, L. (2006). Ethnic, National and Local Identities at Russia's Baltic Borders, p. 22. Retrieved: https://research.utep. edu/LinkClick.aspx?link=008.pdf\&tabid=24748\&mid=80672. Access: 06.02.2018.

4. Castanho, R., Loures L., Fernandez, J. and Pozo, L. (2016). Identifying Critical Factors for Success in Cross Border Cooperation (CBC) development projects, Habitat International, Retrieved: http://dx.doi.org/10.1016/j.habitatint.2016.10.004. Access: 08.11.2017.

5. Daume, S., Quantitative Survey of Inhabitants of Aluksne Municipality $(N=200)$, conducted on December 2016.

6. De Sousa, L. (2013). Understanding European Cross-Border Cooperation: A Framework for Analysis, Journal of European Integration, 35 (6), pp. 669-687. Retrieved:

http://www.tandfonline.com.ezproxy.utlib.ut.ee/doi/pdf/10.1080/07036337.2012.711827?needAccess=true . Access: 16.01.2018.

7. Dukulis, A., Aluksne County Municipality, interview on 7 July 2017.

8. Ede, inhabitant of Misso Parish, interview on 25 May 2016.

9. Fratczak-Muller, J. \& Mielczarek-Zejmo, A. (2016). Cross-Border Partnership - the Impact of Institutions on Creating the Borderland Communities (the Case of Spree-Neisse-Bober Euroregion), Innovation: The European Journal of Social Science Research, 29 (1), pp. 77-97. Retrieved: http://dx.doi.org/10.1080/13511610.2015.1098523. Access: 16.01.2018.

10. Golunov, S. (2013). EU-Russian Border Crossing: The Dialogical Perspective, Geopolitics, 18 (4), pp. 933953. Retrieved:

http://www.tandfonline.com.ezproxy.utlib.ut.ee/doi/pdf/10.1080/14650045.2013.789867?needAccess=true . Access: 16.01.2018.

11. Gonzalez-Gomez, T. \& Gualda, E. (2014). Cross-Border Networks in Informal and Formal Cooperation in the Border Regions Andalusia-Algarve-Alentejo and South Finland-Estonia, European Planning Studies, 22 (7), pp. 1407-1424. Retrieved: http://dx.doi.org/10.1080/09654313.2013.789487. Access: 22.01.2018.

12. Gotmans, J., Haanja Municipality, interview on 25 May 2016. 
13. INTERREG Estonia - Latvia. Retrieved: https://estlat.eu/en/about-estlat/interreg-estonia-latvia\#. Access: 22.01.2018.

14. Latvia - Russia Cross-Border Cooperation Programme. Retrieved: http://latruscbc.eu/about-theprogramme/objective-priorities/. Access: 16.01.2018.

15. Mark, J., Rouge Municipality, interview on 25 May 2016.

16. Nikopensius, I., INTERREG Estonia-Latvia, interview on 7 March 2017.

17. Perkmann, M. (2003). Cross-Border Regions in Europe: Significance and Drivers of Regional Cross-Border Cooperation, European Urban and Regional Studies, 10 (2), pp. 153-171. Retrieved: http://journals.sagepub.com.ezproxy.utlib.ut.ee/doi/pdf/10.1177/0969776403010002004. Access: 16.01.2018.

18. Prizavoite, A., Aluksne County Municipality, Planning and Development Department, interview on 7 July 2017.

19. Raidma, M., Misso Municipality, interview on 25 May 2016.

20. Rozite, M., Cultural Center of Veclaicene, interview on 8 July 2017.

21. Sarmite, inhabitant of Voru County, interview on 8 March 2017.

22. Solveiga, inhabitant of Aluksne City, interview on 26 May 2016.

23. Tali, T., Voru County Development Agency, interview on 10 March 2017.

24. The Cabinet of Ministers of the Republic of Latvia (2010). Regulations No.468. Par Latvijas Republikas valdibas un Krievijas Federacijas valdibas vienosanos par Latvijas Republikas un Krievijas Federacijas pierobezas teritoriju iedzivotaju savstarpejo braucienu vienkarsosanu, The Cabinet of Ministers of Republic of Latvia, Riga, May 25. Retrieved: http://likumi.lv/doc.php?id=210807. Access: 03.01.2018.

25. The Council of Europe (2012). Cross-Border Co-operation Toolkit, p. 134. Retrieved: https://rm.coe.int/1680747160. Access: 03.01.2018.

26. The ESPON (2007). Cross-Border Cooperation - Cross Thematic Study of INTERREG and ESPON Activities, ESPON, Interact, Luxembourg, p. 58. Retrieved: https://www.espon.eu/sites/default/files/attachments/Cross-Border_Cooperation_web.pdf. Access: 03.01.2018.

27. The Ministry of Environmental Protection and Regional Development of the Republic of Latvia (2013). Regionalas politikas pamatnostadnes 2013.-2019.gadam, MEPRD, Riga, p. 95. Retrieved: http://www.varam.gov.Iv/in_site/tools/download.php?file=files/text/att_planosanas_dok/RPD_2013_2019_I nformativa_dala.pdf. Access: 03.01.2018.

28. The Municipality of Aluksne Region. Starptautiska sadarbiba. Retrieved: http://www.Alūksne.Iv/01_05.php. Access: 08.11.2017.

29. Vahter, B., Municipality of Voru County, interview on 8 March 2017.

30. Vartukapteine, I., Jaunlaicene, Ziemeri and Veclaicene Parish, interview on 25 May 2016.

31. Vitola, D., Markalne and Pededze Parish, interview on 25 May 2016. 